\title{
Magnetic anomalies across Bastar craton and Pranhita-Godavari basin in south of central India
}

\author{
I V RADhakrishna Murthr* and S Bangaru Babu \\ Department of Geophysics, Andhra University, Visakhapatnam 530 003, India. \\ *e-mail: ivr_murthy@yahoo.com
}

\begin{abstract}
Aeromagnetic anomalies over Bastar craton and Pranhita-Godavari $(\mathrm{P}-\mathrm{G})$ basin in the south of central India could be attributed to NW-SE striking mafic intrusives in both the areas at variable depths. Such intrusions can be explained considering the collision of the Bastar and Dharwar cratons by the end of the Archaean and the development of tensile regimes that followed in the Paleoproterozoic, facilitating intrusions of mafic dykes into the continental crust. The $\mathrm{P}-\mathrm{G}$ basin area, being a zone of crustal weakness along the contact of the Bastar and Dharwar cratons, also experienced extensional tectonics. The inferred remanent magnetization of these dykes dips upwards and it is such that the dykes are oriented towards the east of the magnetic north at the time of their formation compared to their present NW-SE strike. Assuming that there was no imprint of magnetization of a later date, it is concluded that the Indian plate was located in the southern hemisphere, either independently or as part of a supercontinent, for some span of time during Paleoproterozoic and was involved in complex path of movement and rotation subsequently. The paper presents a case study of the utility of aeromagnetic anomalies in qualitatively deducing the palaeopositions of the landmasses from the interpreted remanent magnetism of buried intrusive bodies.
\end{abstract}

\section{Introduction}

The Bastar and Dharwar cratons are two of the oldest crustal provinces of the Indian subcontinent. They are believed to have collided and assembled into crustal provinces in the Archaean at between $3000 \mathrm{Ma}$ and $2500 \mathrm{Ma}$. In south of central India, they are juxtaposed across the NW-SE trending Pranhita-Godavari $(\mathrm{P}-\mathrm{G})$ basin and are bordered on the south and the southeast by the Eastern Ghat Mobile Belt (EGMB). The $\mathrm{P}-\mathrm{G}$ basin area is considered a zone of crustal weakness at the contact of these cratons and it, too, responded to the extensional tectonics of the cratons and periodically from Mesoproterozoic onwards. It was the site of deposition of Meso and Neoproterozoic marine sediments and the Gondwana fluvial sediments of Upper Carboniferous to the Early Cretaceous. The two cratonic areas contain broadly comparable lithologies with older gneisses, granites, granulites, metasedimentary and metaigneous supracrustal rocks and mafic dykes, but they differ considerably in detail.

South India is more or less completely covered by aeromagnetic surveys by the Geological Survey of India (e.g., Reddi et al 1988), but published reports based on these maps are very few. These maps are, however, available for purchase. Anand and Rajaram (2003) utilizing these maps claimed to have successfully demarcated the boundaries of the various tectonic blocks. Mishra et al (1987), in probably the first regional ground magnetic survey that completely covered the $\mathrm{P}-\mathrm{G}$ basin, predicted from the magnetic anomalies the presence of mafic intrusions in the basement, outside and below the PG basin. The intrusions inferred by them varied in thickness from 10 to $30 \mathrm{~km}$ and were located between the depths 6 and $13 \mathrm{~km}$. The

Keywords. Aeromagnetic anomalies; Bastar craton; Pranhita-Godavari basin; mafic dykes; Gondwana land. 


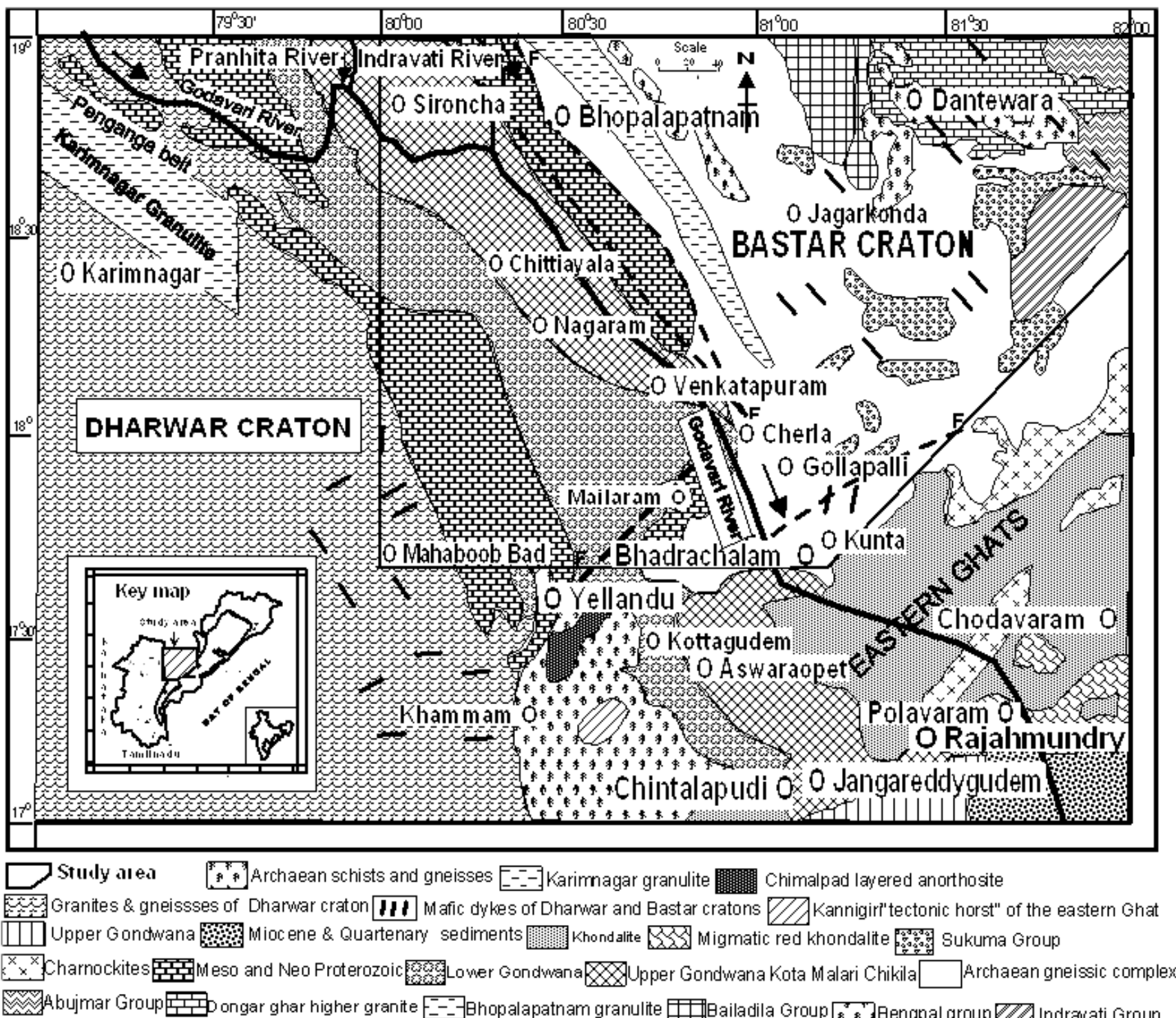

Figure 1. Geology of the study area (source GSI map).

intrusives that flanked the basin were interestingly located below the gravity highs on either side of the basin. While reports concerning the interpretation of aeromagnetic anomalies over the Bastar craton are quite few, gravity anomalies over the craton were vigorously interpreted by Niraj Kumar et al (2004), Subrahmanyam and Verma (1986) and Radhakrishna Murthy et al (2005). Based on the modeling of gravity data, Radhakrishna Murthy et al (2005) predicted a rise in the Moho below the Bastar craton. In the present paper, the aeromagnetic maps over the area bounded by $17^{\circ} 45^{\prime}-19^{\circ} \mathrm{N}$ latitude and $80^{\circ}-82^{\circ} \mathrm{E}$ longitude, covering parts of the $\mathrm{P}-\mathrm{G}$ basin and the Bastar craton, were analyzed and an anomaly profile across the two was modelled. The exercise brought out intrusives into the basement below the PG basin as well as the Bastar craton, supporting the hypothesis of Mishra et al (1987). The magnetization of the intrusives is used to infer qualitatively the paleo-position of the Indian plate during the Paleoproterozoic.

\section{Geology and tectonics of the area}

The geology of the Bastar craton and of the $\mathrm{P}-\mathrm{G}$ basin is shown in figure 1 (after GSI 1998), which includes the exposed rock types viz., granulites and gneisses of the Dharwar craton. The central part of the NW-SE trending $\mathrm{P}-\mathrm{G}$ basin is occupied by the Gondwana sediments, while the western and eastern parts are exposed by the Meso and Neo-proterozoic Pakhal-PengangaSullavai and Albaka-Sullavai group of sediments respectively, with the Gondwanas being deposited over the Proterozoic sediments unconformably. 


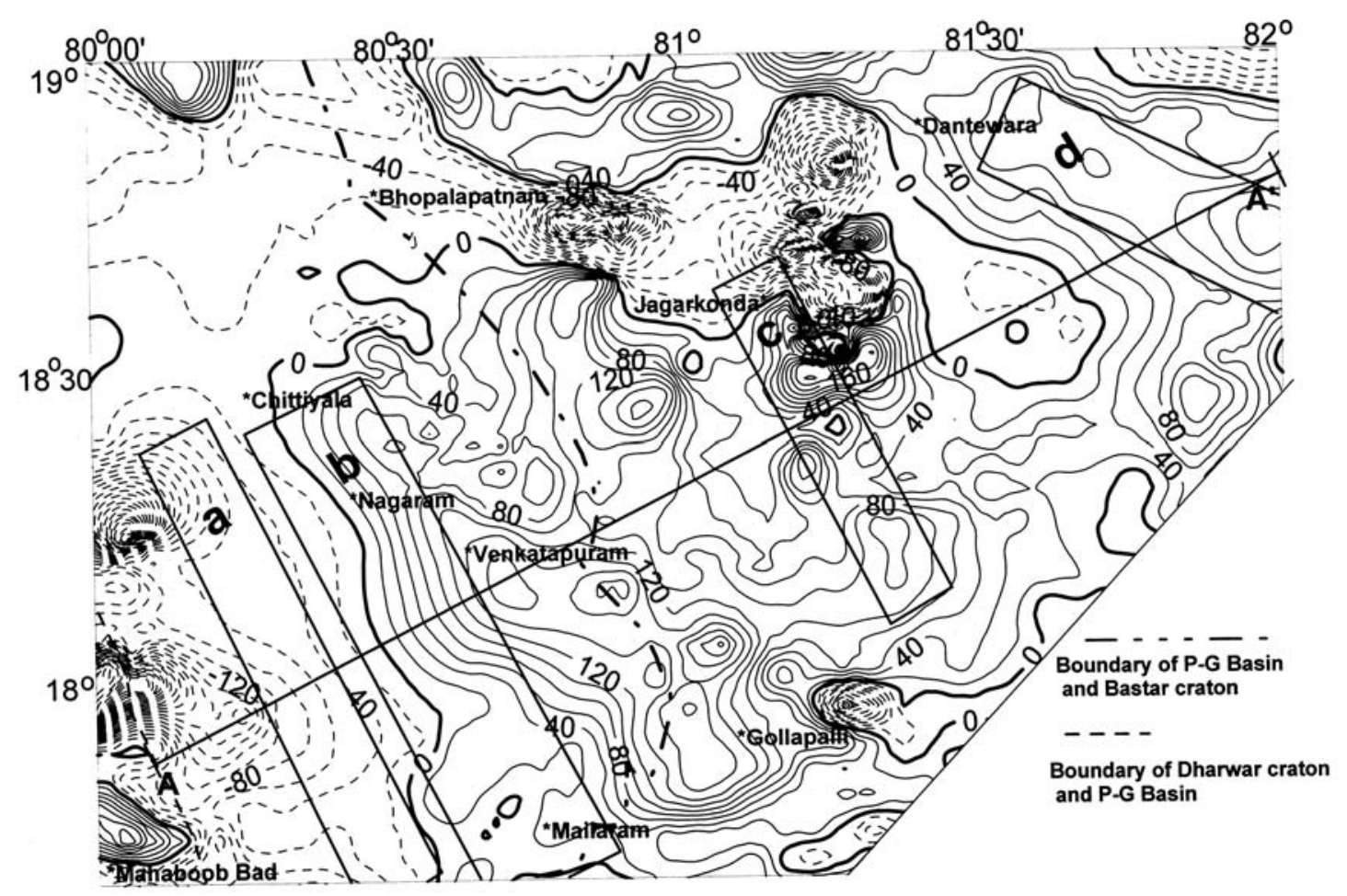

Figure 2. Aeromagnetic anomalies of the Bastar craton and the $\mathrm{P}-\mathrm{G}$ basin.

Most of the Bastar craton exposes the Archaean gneisses as well as some Dongarghar granites of Paleoproterozoic, and volcano-sedimentary sequences of Bailadila group and Abujmar group of rocks at around Dantewara. The Neo-proterozoic sedimentary basin (Indravati basin) is also identified in this craton. Bhopalapatnam granulites are found in a narrow NNW-SSE trending belt west of Bhopalapatnam. Pockets of Archaean supracrustal, Sukuma-Bengapal group of rocks are widespread and the mafic dyke swarms of subalkaline nature (Srivastava and Singh 2003) are profuse. The younger set of these sub-alkaline mafic dykes are believed to be of Paleoproterozoic (1.8 Ga) (Srivastava and Singh 2003). Some of the dykes in the Karimnagar area, close to the present area of interest, are palaeomagnetically dated to be $1800 \pm 200 \mathrm{Ma}$ (Subba Rao and Radhakrishna Murthy 1985). They exhibited both normal and reverse magnetizations and it was inferred that they were emplaced during a short span of time, during which there was a change in the earth's magnetic field direction.

\section{Magnetic anomalies}

Aeromagnetic data in the present study was procured from the Airborne Mineral Survey \& Exploration (AMSE) wing of the Geological Survey of India, which collected and published the data in the form of total intensity contour maps in degree sheet format. The data relating to the present study was collected during 1989-1990 along N-S orientation flight lines with a line spacing of $4000 \mathrm{~m}$ at an altitude of $1500 \mathrm{~m}$. It is covered by four degree sheets $65 \mathrm{~B}, 65 \mathrm{C}, 65 \mathrm{~F}$ and $65 \mathrm{G}$ bounded by $17^{\circ}$ to $19^{\circ} \mathrm{N}$ latitudes and $80^{\circ}$ and $82^{\circ} \mathrm{E}$ longitudes. The data on these sheets were digitized at an interval of 3 minutes, and the magnetic anomalies were calculated by removing the normal geomagnetic field values from the observed values. For the purpose of calculation of normal values, IGRF 1990 coefficients were made use of employing FORTRAN program IGRF developed by Radhakrishna Murthy (1998).

The anomalies are shown in figure 2 contoured generally at an interval of 20 gammas. Approximate geological boundaries between the Dharwar craton and $\mathrm{P}-\mathrm{G}$ basin, and the $\mathrm{P}-\mathrm{G}$ basin and Bastar craton are also indicated by discontinuous lines in this figure. The anomalies varied in magnitude from -200 to +200 gammas, although anomalies of larger magnitude could be identified at isolated places. The anomalies east of $80^{\circ} 30^{\prime} \mathrm{E}$ longitude are conspicuously positive, but for an almost E-W trending strong negative anomaly along the $18^{\circ} 45^{\prime} \mathrm{N}$ latitude.

The Bastar craton is dominantly occupied by positive anomalies to be intervened only by the $\mathrm{E}-\mathrm{W}$ trending negative anomaly along the $18^{\circ} 45^{\prime} \mathrm{N}$ latitude. The broad wavelength positive anomaly 
covering the Bastar craton and the right flank of the Godavari basin deceptively appears to be due to the contact between the craton and the sediments. This possibility can, however, be ruled out as will be explained later. Similar is the case of the strong negative anomaly closures associated with the contact between the Godavari sediments and the Dharwar craton. The anomaly closures on the S-W corner of the map that lie within the Dharwar craton can be easily attributed to the dolerite dyke swarms, that occur in this craton. Thus the boundaries between the $\mathrm{P}-\mathrm{G}$ basin and Bastar craton, and the Dharwar craton and $\mathrm{P}-\mathrm{G}$ basin cannot be distinguished from the trends and/or magnitudes of the anomalies. This is to indicate that the surface rocks of either unit are not the cause of the anomalies, and the anomalous bodies clearly lie at depth.

The $\mathrm{P}-\mathrm{G}$ basin, in particular, is typically associated with a NW-SE trending positive anomaly passing through Gollapalli, Venkatapuram and Nagaram. This trend which is parallel to the general trend of the rocks of the $\mathrm{P}-\mathrm{G}$ basin, is juxtaposed on its west by an equally strong trend of negative anomaly. This bipolar-trend is, however, of limited extent being truncated along the $18^{\circ} 45^{\prime} \mathrm{N}$ latitude near Chittiayala, indicating that the source causing these anomalies has only a finite strike length. This is to imply that the Gondwana sediments that occupy the $\mathrm{P}-\mathrm{G}$ basin continuously throughout its length are not the source of anomaly. The magnitude of the observed anomalies also rule out the sedimentary rocks of the $\mathrm{P}-\mathrm{G}$ basin to be the source of anomalies, since these rocks do not have enough magnetic susceptibility to generate the magnitude of anomalies of the order of 200 gammas at an elevation of $1.5 \mathrm{~km}$.

Another conspicuous feature of the anomalies over the Bastar craton is the NW-SE trend passing through Dhantewara. It is not clear if the hematite rich Bailadila group of rocks, with $\mathrm{N}-\mathrm{S}$ orientation on the geological map (figure 1), is conspicuously brought out on the anomaly map, because of the interference of a strong magnetic anomaly closure. The few anomaly closures south of Jagarakonda may be attributed to the mafic dyke swarms in the Bengpal group and the gneisses of the Bastar craton.

\section{Inversion}

Serious efforts to attribute the different components of anomalies to contacts between the Dharwar craton and Godavari basin on one hand, and the Godavari basin and Bastar craton on the other could not yield satisfactory results. For instance, the long wavelength anomaly covering the Bastar craton and extending into the Godavari basin can be qualitatively attributed to the contact between the Godavari sediments and Bastar craton. If so, the anomaly should be sharp at the contact, whereas the observed one is very broad. Further, a couple of magnetic anomaly profiles cutting the Godavari basin and Bastar craton, when inverted for a fault model/contact, gave unrealistic interpretations putting the dip of the fault/contact at 10 degrees. Hence the idea of attributing the anomaly to the contact between the Godavari basin and Bastar craton was abandoned.

A typical magnetic profile $\left(\mathrm{AA}^{\prime}\right)$ running NE-SW over a length of $260 \mathrm{~km}$ across the important NW-SE trends was therefore constructed (figure 3) and inverted variously in terms basement structures as well as dyke models at depth. This profile shows initially a low of negative magnetic anomaly followed by a high of positive anomaly over the region occupied by the Gondwana sediments, as well as a dominant high at the right extreme over the Bastar craton. Another high, although narrow in width, can also be noticed around $150 \mathrm{~km}$, which occurs over the Bastar craton.

Inversion was attempted by splitting the profile by inspection into isolated components and attributing each component to a specific geophysical model including magnetic interfaces. Here again attempts to fit the anomalies to faulted strata at depth, or structures on magnetic interfaces miserably failed with unrealistic model parameters. When the anomalies were attributed to structures in the basement, for example, inversion showed that such a basement cannot be deeper than a kilometer even at stations where the known depths of the Godavari sediments exceed $3.0 \mathrm{~km}$. The trials also ruled out that the anomalies could be attributed to any lateral magnetic contrast between the rock units within the $\mathrm{P}-\mathrm{G}$ basin and the Bastar craton, or between those of the two. However, the attempt to fit the anomalies to possible dyke models was successful.

The method used for inversion of dykes in this exercise is that of Radhakrishna Murthy (1998), which not only calculates the model parameters, but also identifies the linear regional anomaly associated with the profile. The method also does not require a priori calculation of the initial values of the model parameters, which exercise forms a built-in component of the method. The algorithm scans the profile, identifies characteristic anomalies and distances, calculates the initial parameters and improves them iteratively through Marquardt's optimization procedure. The present profile was successfully split into four components, by trial and error, in the following way: The profile was split by 


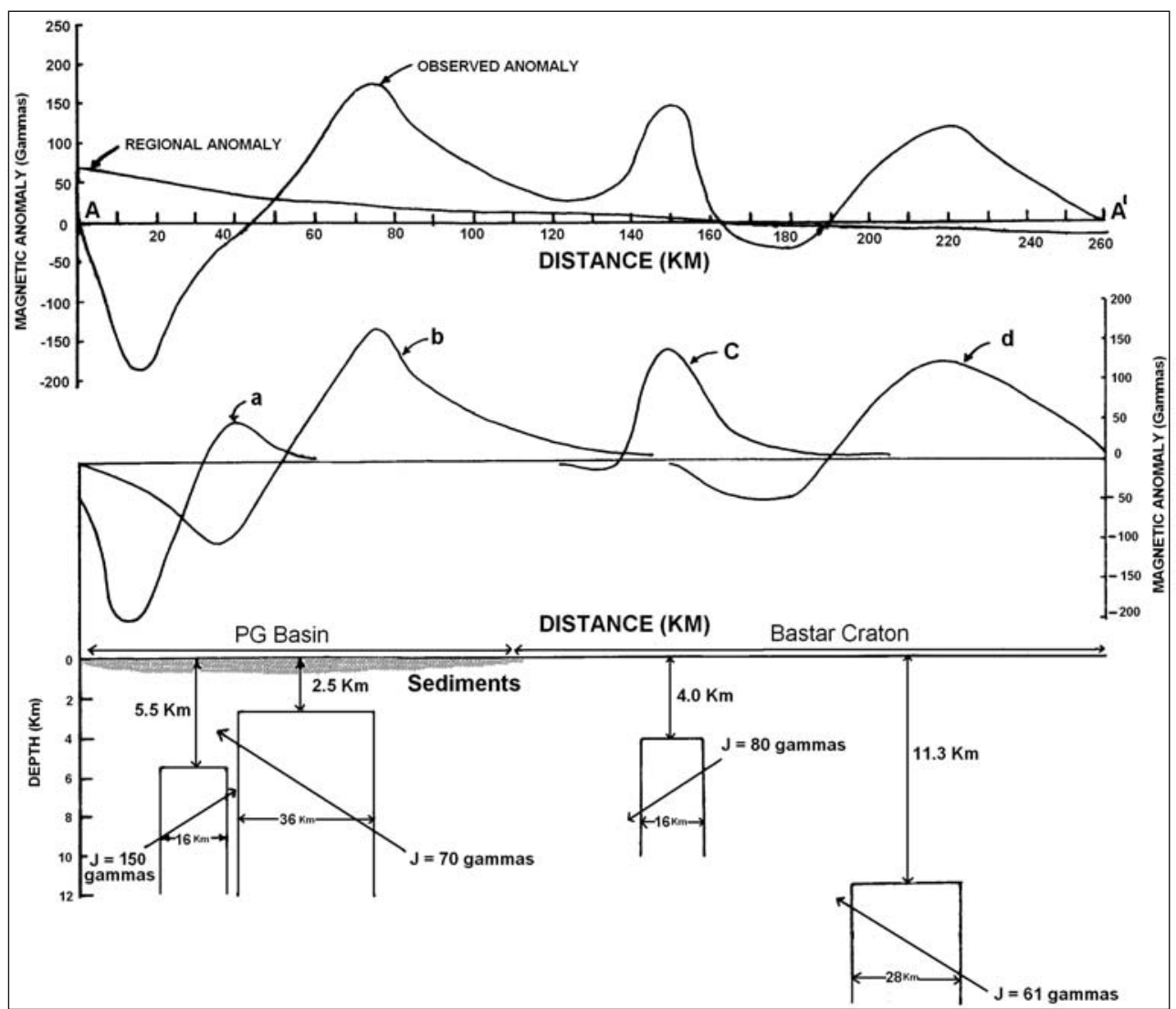

Figure 3. Inverted dyke models at varying depths. Note that the length of the vectors are not in proportion to the magnitude of the effective magnetization.

Table 1. Interpreted parameters of the dyke models.

\begin{tabular}{|c|c|c|c|c|c|c|}
\hline \multirow{3}{*}{$\begin{array}{l}\text { Dyke } \\
\text { no. }\end{array}$} & \multirow{3}{*}{$\begin{array}{l}\text { Depth to } \\
\text { top }(\mathrm{km})\end{array}$} & \multirow{3}{*}{$\begin{array}{l}\text { Width } \\
(\mathrm{km})\end{array}$} & \multicolumn{2}{|c|}{ Effective magnetization } & \multirow{2}{*}{\multicolumn{2}{|c|}{ Objective function for* }} \\
\hline & & & \multirow{2}{*}{$\begin{array}{l}\text { Intensity } \\
\text { (gammas) }\end{array}$} & \multirow{2}{*}{$\begin{array}{c}\text { Dip } \\
\text { (degree) }\end{array}$} & & \\
\hline & & & & & Initial model & Final model \\
\hline $\mathbf{a}$ & 5.5 & 16 & 150 & 235 & 27412 & 631 \\
\hline b & 2.5 & 36 & 70 & 120 & 28809 & 2759 \\
\hline c & 4.0 & 16 & 80 & 180 & 821 & 86 \\
\hline d & 11.3 & 28 & 61 & 290 & 13465 & 830 \\
\hline
\end{tabular}

* Objective function is defined as the sum of the squares of errors.

inspection into $\mathbf{a}, \mathbf{b}, \mathbf{c}$ and $\mathbf{d}$ and each component was subjected to inversion. Since the profile used in interpretation is regional free, inversion of $\mathbf{a}, \mathbf{b}$, $\mathbf{c}$ and $\mathbf{d}$ components should bring out zero regional values below each of them. The splitting of the profile into $\mathbf{a}, \mathbf{b}, \mathbf{c}$ and $\mathbf{d}$ is thus made by trial and error, the correct choice obviously corresponding to the one which predicted zero regional values everywhere.

The resultant interpretation is provided in figure 3 , which shows the four dyke models, named a, $\mathbf{b}, \mathbf{c}$ and $\mathbf{d}$, needed to explain the anomalies along with the magnitude and direction of magnetization of each of them. The parameters of the dykes and the drop in the objective function between the first and final iterations are further shown in table 1. Two of these dykes $\mathbf{a}$ and $\mathbf{b}$ occur below the $\mathrm{P}-\mathrm{G}$ basin to explain the NW-SE trending anomaly pair of negative and positive values. These dykes are placed at depths of $5.5 \mathrm{~km}$ and $2.5 \mathrm{~km}$ respectively, the values of which are larger than the known thickness values of the sediments in $\mathrm{P}-\mathrm{G}$ basin at the respective positions. The other two dykes $\mathbf{c}$ and $\mathbf{d}$ lie within the Bastar craton. While the dyke $\mathbf{c}$ is at a depth of $4.0 \mathrm{~km}, \mathbf{d}$ is at a larger depth of $11.3 \mathrm{~km}$. The conspicuous E-W trending negative anomaly along the $18^{\circ} 45^{\prime} \mathrm{N}$ latitude is then attributed to the effects of the edges of these dykes. 


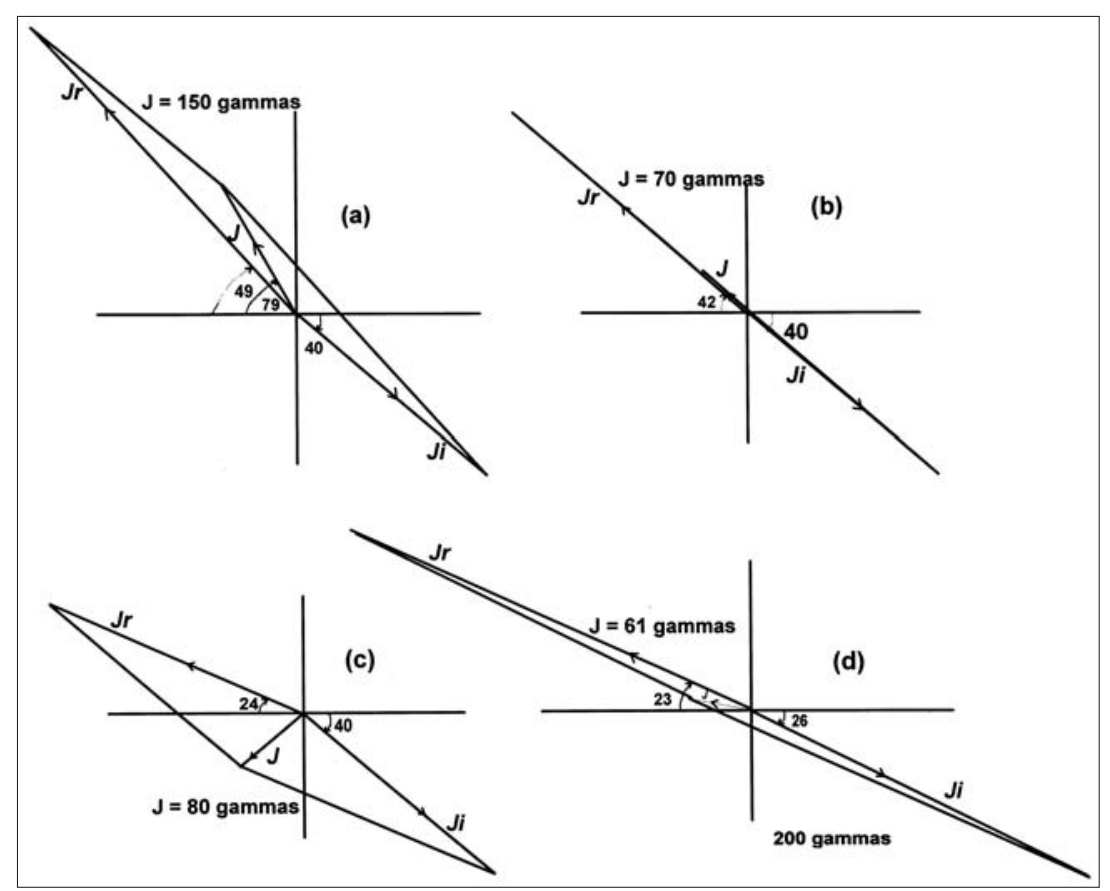

Figure 4. Calculation of effective remanent magnetizations $J, J_{i}$ and $J_{r}$ are the resultant, induced and remanent components respectively.

\section{Discussion}

The emplacement of dykes into the basement of the $\mathrm{P}-\mathrm{G}$ basin is in accordance with the interpretation of Mishra et al (1987), which predicted similar dykes elsewhere in the $\mathrm{P}-\mathrm{G}$ basin. The presence of dyke swarms in the Bengpal group of rocks and the gneisses of the Bastar craton stand in support of the inferred intrusions into this craton. The possible emplacement of the dykes into the Bastar craton and the $\mathrm{P}-\mathrm{G}$ basin is further visualized in the totality of the regional tectonics. Following the collision of the Bastar and Dharwar cratons, a tensile regime would have developed in the two cratonic areas during the Paleoproterozoic, facilitating intrusion of mafic dykes intermittently into the continental crust. The Pranhita-Godavari basin that developed along the contact of the Dharwar and Bastar cratons, is itself a zone of crustal weakness, the basement rocks of which are capable of positively responding to the extensional tectonics.

Utilizing the calculated values of magnetizations of the dykes, an attempt was made to assess the directions of remanent magnetizations in them and to locate the Indian plate in the Precambrian time. In case of two-dimensional bodies, the components of magnetization parallel to their strike do not provide any anomalies and the effective magnetization $J$, lying in a plane perpendicular to the strike of the body, dips at an angle $\phi$, which is different from the true dip $\phi_{\text {true }}$ of magnetization. $J$ and $J_{\text {true }}$, and $\phi$ and $\phi_{\text {true }}$ are connected by the relations

$$
J=J_{\text {true }} \sqrt{1-\cos ^{2} \phi_{\text {true }} \cos ^{2} \alpha}
$$

and

$$
\phi=\arctan \left(\frac{\tan \phi_{\text {true }}}{\sin \alpha}\right)
$$

where $\alpha$ is the angle between the strike of the body and the meridian containing the magnetization vector. Clearly $\phi_{\text {true }}$ is always greater than or equal to the true dip of magnetization. Bodies with a susceptibility value of about $0.06 \mathrm{cgs}$ units equivalent to that of a rock of $2 \%$ of magnetite by volume and striking $\mathrm{N} 30^{\circ} \mathrm{W}$, as in the present case $(\mathbf{a}, \mathbf{b}$, c in figure 3), when exposed to the earth's magnetic field of 43,000 gammas and dipping at $23^{\circ}$, will have an effective induced magnetization of 150 gammas dipping at $40^{\circ} \mathrm{E}$. Similarly the effective induced magnetization of the dyke $\mathbf{d}$ with a $\mathrm{N} 60^{\circ} \mathrm{W}$ strike is 230 gammas dipping at $26^{\circ} \mathrm{E}$. The magnetizations plotted in figure 3 for the dykes are indeed effective magnetizations, and they are the resultant of the effective induced and effective remanent components. The calculated magnetizations in all the four cases appreciably deviate from that of the induced magnetization. They are consistently oriented towards the west of the anomalous bodies and dip upwards except in the case of dyke $\mathbf{c}$. 
To explain the calculated resultant magnetizations, one needs to invoke a remanent magnetization in all the four cases which dips upwards and is oriented towards the west of the body. The calculation of the effective remanent magnetizations based on the parallelogram law of vectors using the assumed/known values of the effective induced and resultant magnetisms is illustrated in figure 4 . The values of intensity and dip of effective remanent magnetization, as reported here, are only indicative and valid for bodies of magnetic susceptibility equivalent to those with $2 \%$ to $3 \%$ magnetite by volume. Nevertheless, these values will not be qualitatively different for marginally different susceptibility values to seriously affect the conclusions. The up dip of remanent magnetization may indicate that the dykes were emplaced in the earth's normal magnetic field, when the landmass was in the southern hemisphere. The dips average out to $-35^{\circ}$, indicating that the (average) remanent magnetization cannot dip upwards by more than $35^{\circ}$ and the landmass cannot be farther away by $19^{\circ}$ south of the equator. The westward orientation of remanent magnetization with reference to the strike of the body suggests that the intrusives striked towards the east of the north, at the time of their cooling, as against their present NW-SE orientation. It is then obvious that the landmass should have rotated several degrees anticlockwise, after the intrusives cooled and retained their remanent magnetism. In drawing these inferences, it is assumed that the calculated remanent magnetism is primary and it was not affected by later events.

An alternative and improbable scenario is that the dykes would have been emplaced when the landmass was in the northern hemisphere and when the earth's magnetic field was normal. If so, the landmass would have been at approximately the same position as it is today, and it should have undergone little or no rotation, and/or it should have returned to its original position after several excursions over the past 1800 million years.

It is well known that the Indian plate had a complex path of movement during the Proterozoic. The present exercise thus suggests that the Indian plate individually or as part of a supercontinent was in the southern hemisphere for some span in
Paleoproterozoic and was involved later in complex movements and rotation.

\section{Acknowledgements}

This work is carried out in the Emeritus Scientist Scheme awarded by the CSIR to the senior author and the financial support from the CSIR is gratefully acknowledged. The authors specially thank Prof. T Ramamohana Rao, Retired Professor of Geology, Andhra University, Visakhapatnam for geological inputs, useful discussions and improving the manuscript.

\section{References}

Anand S P and Mita Rajaram 2003 Study of aeromagnetic data over part of Eastern Ghat Mobile Belt and Bastar craton; Gondwana Res. 6 859-865.

GSI 1998 Geological Map of India, 7th edn, published by Geological Survey of India.

Mishra D C, Gupta S B, Rao M B S V, Venkatarayudu $\mathrm{M}$ and Laxman G 1987 Godavari basin - a geophysical study; J. Geol. Soc. India 30 469-476.

Niraj Kumar, Singh A P, Gupta S B and Mishra D C 2004 Gravity signature, crustal architecture and collision tectonics of the Eastern Ghats Mobile Belt; J. Ind. Geophys. Union 8(2) 97-106.

Radhakrishna Murthy I V 1998 Gravity and magnetic interpretation in exploration geophysics; Geol. Soc. India Memoir 40 181-189.

Radhakrishna Murthy I V, Rama Rao P, Sudhakar K S and Bangaru Babu S 2005 Moho structure beneath the Eastern Ghat Mobile Belt and adjacent Bastar craton as deduced from gravity anomalies; J. Ind. Geophys. Union 9(3) $167-171$.

Reddi A G B, Mathew M P, Singh B and Naidu P S 1988 Aeromagnetic evidence of crustal structure in the granulite terraine of Tamil Nadu-Kerala; J. Geol. Soc. India 32 368-381.

Srivastava R K and Singh R K 2003 Geochemistry of high mafic dykes from the Bastar craton: Evidence of late Arcaean boninite-like rocks in an intracratonic setting; Curr. Sci. 85(6) 808-811.

Subba Rao Y V and Radhakrishna Murthy I V 1985 Palaeomagnetism and ages of dolerite dykes in Karimnagar District, Andhra Pradesh, India; Geophys. J. R. Astr. Soc. $82331-337$.

Subrahmanyam C and Verma R K 1986 Gravity field structure and tectonics of the Eastern Ghats; Tectonophys. 126 195-212. 